\title{
ENTRE NARRATIVA HERÓICA E POESIA RITUAL: O SUJEITO POÉTICO QUE CANTA O MITO
}

\author{
CLAUDE CALAME \\ École des Hautes Études en Sciences Sociales (França)
}

\begin{abstract}
RESUMO: $O$ cruzamento da perspectiva aberta pelas pesquisas de Benveniste sobre a enunciação entre narrativa (enunciado) $e$ discurso (enunciado da enunciação) e aquelas de Bühler sobre os procedimentos da dêixis a partir do ponto focal que constitui o eu discursivo tem um impacto não somente sobre a concepção do autor e de sua autoridade poética, mas também sobre aquela da ficção em geral e do mito em particular, em sua dimensão discursiva. Para a poesia da Grécia clássica, que erigimos em "literatura" a despeito de seu caráter fortemente pragmático, que destina suas formas a performances musicais ritualizadas, não é portanto somente a questão do eu poético (e "lírico") que deve ser considerada sob uma luz nova, mas também aquela das narrativas que denominamos "míticas", porque as dotamos de referência empírica e as assimilamos a ficções. Tomando como exemplo único o poema mélico de Píndaro, pertencente ao gênero do epinício, convém ilustrar esse processo complexo de composição-performance musical que põe tanto a metáfora poética quanto a narrativa heróica a serviço de uma celebração ritual pelo prisma de um jogo enunciativo e pragmático de notável densidade.
\end{abstract}

PALAVRAS-CHAVE: mélos; poesia ritual; narrativa e discurso; "eu lírico".

Hoje sabemos que, na Grécia antiga, não há mito a não ser quando a narrativa é reduzida a seu enredo nos tratados de mitografia de uso erudito. Nem na Grécia antiga, nem em nenhuma outra cultura de tradição essencialmente oral, a narrativa que apreendemos como mítica não existe senão nas formas discursivas que a ela se referem em circunstâncias de enunciação e para um público preciso, na performance cantada. São essas formas que, associadas a uma performance 
oral, conferem dimensão pragmática a narrativas que constroem um mundo possível de ações situadas no tempo e no espaço de heróis e deuses, para nós um mundo de ficção; são essas formas que emprestam referência prática às narrativas que concebemos como mitos em razão da distância cultural que delas nos separa. ${ }^{1} \mathrm{Na}$ Grécia antiga, isso vale sobretudo para os episódios da saga divina e heróica integrados às formas poéticas rituais, e por vezes cultuais do mélos (que concebemos equivocadamente como poesia lírica).

Ora, quem aborda as diferentes formas da poesia mélica grega confrontase com a incontornável questão do "eu lírico": quem assume as formas do eu numa poesia mélica que se caracteriza precisamente pela sua forte presença? Que voz de autoridade encarrega-se da narração poética do mito? Formular essa questão dupla conduz, em geral, a uma contradição: pensando no primeiro Parteneu de Álcman, como justificar, por exemplo, a execução coletiva, por um coro de moças, de um canto que narra uma cena de rivalidade mítica para ilustrar a emoção erótica sentida, mas composta por um poeta masculino, se identificamos o $e u$ verbal diretamente com o autor?

É inútil nos interrogar novamente sobre a natureza do "eu lírico" sem formular a questão em termos lingüísticos de enunciação, ou ainda de autoridade poética para um conteúdo semântico que possui uma forte dimensão pragmática. Antes de toda referência psicológica e biográfica, antes de toda projeção sobre a poesia mélica grega da concepção romântica da lírica como expressão poética dos sentimentos íntimos do poeta, ${ }^{2}$ convém nos concentrar sobre os efeitos de sentido de uma manifestação puramente verbal, de uma instância que se enuncia verbalmente em $\mathrm{eu}$.

1 Remeto-me aqui às reflexões coletivas apresentadas em CALAmE (1988), Métamorphoses du mythe en Grèce antique, e também individuais, mas em referência a outros trabalhos, na Poétique des mythes dans la Grèce antique, Paris: Hachette, 2000, p. 11-69; ver ainda a abundante bibliografia ilustrada oportunamente por Delattre (2005), Manuel de mythologie grecque, p. 6-48.

2 Para uma crítica da aplicação na poesia grega da categoria moderna do "lírico", ver as observações que apresentei sucessivamente em "La poésie lyrique grecque, un genre inexistant?" (Calame, 1998) e em "Identifications génériques entre marques discursives et pratiques énonciatives: pragmatique des genres 'lyriques”' (Calame, 2006). 


\section{As estratégias de enunciação poética}

Para evitar os efeitos da doxa e para adotar uma posição crítica, não é inútil retornar aos textos da partilha hoje canônica traçada por Émile Benveniste entre história (ou narrativa) e discurso. Apresentada num artigo datado de 1959, e retomada na primeira coleção dos Problemas de Lingüística Geral (numa seção intitulada "O homem e a língua"), a distinção inscreve-se de pronto numa lingüística do discurso, chamada a centrar-se sobre a pragmática; uma lingüística a ser considerada desde logo como uma ciência humana, que gostaríamos de desenvolver no sentido de uma antropologia cultural e histórica dos textos. Numa análise crítica da classificação dos tempos gramaticais no francês contemporâneo, Benveniste é levado a afirmar:

A enunciação histórica, hoje reservada à língua escrita, caracteriza a narrativa dos acontecimentos passados. Estes três termos, "narrativa", "acontecimento", "passado", devem ser igualmente sublinhados. Trata-se da apresentação de fatos que sobrevêm em certo momento do tempo, sem nenhuma intervenção do locutor na narrativa (...). Definiremos a narrativa histórica como o modo de enunciação que exclui toda forma lingüística "autobiográfica". O historiador jamais dirá eu nem tu, nem aqui, nem agora, porque jamais tomará emprestado o aparato formal do discurso, que consiste em primeiro lugar na relação pessoal $\mathrm{eu}: \mathrm{tu} .^{3}$

Se, nesse primeiro estudo sobre a enunciação histórica, Benveniste concentra sua atenção na dimensão narrativa, os dois capítulos seguintes dos Problemas de Lingüística Geral são consagrados à "natureza dos pronomes" e à "subjetividade na linguagem". Encontramos ali uma série de reflexões e de interrogações quanto à "realidade" a que se referem as formas do eu ou do tu em cada "instância do discurso", ou seja, em cada ato distinto no qual "a langue atualiza-se em parole por meio de um locutor". ${ }^{4}$ Daí o princípio fundamental segundo o qual, como pronome, o eu (verbal) remete somente a uma "realidade do discurso": "Eu significa a pessoa que enuncia a presente instância do discurso que contém eu" e portanto "a forma eu possui existência lingüística somente no ato de parole que a profere".

3 Benveniste, 1966, p. $237-250$ (p. 239 para a citação), retomando um artigo publicado no Bulletin de la Société de Linguistique, v. 54, 1959.

4 Benveniste, 1966, n. 3, p. 251-257 e p. 258-266 (p. 251 e 252 para as citações). 
Assim se desenha, de maneira praticamente implícita, a distinção essencial entre, de uma parte, o eu que, como forma pronominal e verbal, possui apenas uma existência e uma referência de ordem lingüística, e, de outra parte, o "locutor" (ou antes "o enunciador") que é o sujeito (psicossocial) do ato de parole. Se devem ser considerados somente como "categorias da linguagem", eu e tu são no entanto o objeto de uma localização espacial e temporal. Essa localização corresponde aos parâmetros lingüísticos e enunciativos do aqui e do agora. A partir dessas primeiras constatações decorrentes da distinção entre "história/narrativa" e "discurso", define-se em primeiro lugar o que Benveniste chamará um pouco mais tarde de "aparato formal da enunciação": realidade puramente verbal, ego encontra-se no centro desse sistema enunciativo definido pelos "indicadores de dêixis" espaciais e temporais (Benveniste, 1974). De resto, essas observações fundamentais sobre os índices da enunciação distinta do enunciado conduzem ao esboço de uma teoria dos atos de linguagem; as instâncias de discurso que contêm formas em primeira pessoa como eu juro ou eu prometo remetem a enunciados cuja "enunciação identifica-se com o próprio ato".

Aliás, os critérios lingüísticos formulados por Benveniste para distinguir do "discurso" os enunciados pertinentes à "história/narrativa" correspondem às marcas formais da narrativa mítica: atores-eles situados num tempo suspenso e num espaço outro em relação àqueles da enunciação (enunciado). São os nomes próprios e as diferentes qualidades atribuídas aos protagonistas da ação narrativa que a inscrevem na ordem daquilo que chamamos de mitologia.

Pioneiro, Benveniste ignora no entanto os trabalhos e o grande livro de Karl Bühler, que lhe é anterior. A partir de 1934, o lingüista alemão consagrou diversos capítulos de sua Sprachtheorie aos diferentes processos da demonstração verbal, com base em partículas anafóricas e demonstrativos. Indo além do horizonte de uma lingüística frástica, ele relevou assim em toda forma de discurso "ein Hier-Jetzt-Ich System" cujo ponto de partida é constituído pelo eu verbal em suas diferentes formas. Ao estruturar um "campo da demonstração" (Zeigfeld), esse sistema desdobra-se, graças às potencialidades da língua, em dois planos: de um lado, refere-se àquilo que os interlocutores (os enunciadores) têm sob os olhos (por meio de processos de referência dêitica extra-discursivos); de outro, recorre ao ouvido e ao olho interiores da platéia ou do leitor (por meio de processos de demonstração intra-discursivos, de ordem anafórica e catafórica). Os processos da demonstratio ad oculos combinam-se portanto, em praticamente toda forma de discurso, com os processos da Deixis am Phantasma (Bühler, 1934, p. 102-148). 
Sob uma perspectiva de interferência, a distinção (operatória) entre Deixis am Phantasma e demonstratio ad oculos é essencial, na medida em que os mesmos demonstrativos, como em grego os demonstrativos em -de, são capazes tanto de evocar o que é criado no e pelo discurso (por meio de anáfora e catáfora) quanto de fazer referência à realidade extra-lingüística. Uma tal capacidade partilhada entre referência interna e referência externa torna, de um lado, porosa a distinção entre "discurso" e "história/narrativa"; a despeito das interrupções enunciativas observáveis no texto, protagonistas, tempo e espaço do mito guardam relação com os atores, o tempo e o espaço da cena enunciativa tal como inscrita no discurso. De outro lado, ela confirma a permeabilidade de fato entre o intra- e o extradiscursivo, roubando por exemplo à ficção, e portanto ao mito, toda pretensão à autonomia semântica como mundo possível. Convém, assim, transportar do plano (agora puramente operatório) da narrativa sobre aquele do discurso a combinação possível dos dois procedimentos da Deixis am Phantasma e da demonstratio ad oculos. Entre evocação verbal endereçada à imaginação e designação da realidade extralingüística, esse duplo processo demonstrativo diz respeito tanto à instância da narração quanto ao que chamo "instância de enunciação", com seus parâmetros espaciais e temporais, no sistema do ego/tu - hic - nunc.

Isso equivale a dizer que, antes de toda referência extra-discursiva, constrói-se no discurso, por meios lingüísticos, uma figura de autor que é puramente verbal: trata-se da figura do narrador ou, mais precisamente, do locutor-eu que muitas vezes se defronta com um interlocutor-tu (figura ela própria puramente verbal). Ao desenvolver-se em postura enunciativa, dotada de um ethos discursivo, essa figura semântica remete apenas de maneira mediata ao autor considerado em sua função institucional, como figura social definida por sua "função-autor", para retomar a idéia avançada por Michel Foucault. Mas, na poesia grega, quem diz "função-autor" diz também "função-executante", uma vez que a performance poética que canta o mito é assumida pelos atores de uma ocasião ritualizada: aedo ou rapsodo, grupo coral, atores do drama trágico ou cômico etc. ${ }^{5}$ É somente por esse viés a princípio discursivo, depois institucional, que a figura do locutor-eu remete finalmente ao autor em sua realidade histórica, com sua intencionalidade e sua criatividade (uma criatividade cuja natureza será de ordem psicológica, psicanalítica, mental, cognitiva, neurológica ou social de acordo com a perspectiva que seja

5 Para uma apresentação dessa noção e uma avaliação do valor operatório da noção de "função-autor" para as diferentes formas de discursos antigos, remeto-me a Calame e Chartier (2004), Identités d'auteur dans l'Antiquité et la tradition européenne. 
adotada) (cf. Calame, 2005, p. 13-40); é somente por esse viés enunciativo que o canto confere sobretudo à narração do mito a autoridade que se remete a uma comunidade de crenças, assegurando sua eficácia cultural e social.

O cruzamento da perspectiva aberta pelas pesquisas de Benveniste sobre a enunciação entre narrativa (/enunciado) e discurso (enunciado da enunciação) e aquelas de Bühler sobre os procedimentos da dêixis a partir do ponto focal que constitui o eu discursivo tem um impacto não somente sobre a concepção do autor e de sua autoridade poética, mas também sobre aquela da ficção em geral e do mito em particular, em sua dimensão discursiva. Para a poesia da Grécia clássica, que erigimos em "literatura" a despeito de seu caráter fortemente pragmático, que destina suas formas a performances musicais ritualizadas, não é portanto somente a questão do eu poético (e "lírico") que deve ser considerada sob uma luz nova, mas também aquela das narrativas que denominamos "míticas", porque as dotamos de referência empírica e as assimilamos a ficções. Ora, como afirmamos de início, na Grécia antiga e em outras culturas tradicionais o mito - abstração moderna canonizada por antropólogos e filósofos - existe somente nas formas poéticas que tornam as narrativas eficazes junto a um público ativo em dadas circunstâncias rituais, sociais e culturais. ${ }^{6} \mathrm{Ou}$ seja, todo enunciado mítico depende de regras (verbais e sociais) do gênero poético que o corporifica em enunciação, em condições particulares. Em geral ritual, a situação de enunciação insere a respectiva composição poética, por ocasião de sua performance, nas homenagens cultuais prestadas a uma divindade, num espaço que lhe é consagrado: através de diversos procedimentos de ordem enunciativa, o poema aparece como um ato de canto, e portanto como um ato de culto. ${ }^{7}$ Através desse viés enunciativo e performativo, a narrativa "mítica" é referida ao hic et nunc das circunstâncias de execução do canto.

Pela pragmática das formas poéticas, a "ficção" do mito grego releva-se um poderoso meio de ação musical e rítmica; por intermédio do poeta, na condição de sophós inspirado, a ação musical funda-se tanto nas capacidades criadoras de uma língua poética tradicional quanto em procedimentos de designação enunciativa e pragmática oferecidos por toda langue enunciada em parole. Essencial nesse senti-

6 Às referências dadas na n. 1, acrescento o estudo "Fiction référentielle et poétique rituelle: pour une pragmatique du mythe (Sappho 17 et Bacchylide 13)" (Delattre, no prelo).

7 Sobre todos esses aspectos "performativos" da poesia grega, em especial quando se trata de poesia coral, ver a valiosa análise proposta por Bierl (2001, p. 11-64). 
do, portanto, é o ponto focal assumido pelo eu do locutor na condição de "instância de enunciação"; ele constitui o ponto de partida dos procedimentos de referência enunciativa para as condições de produção e enunciação daquilo que é enunciado no poema, em particular na narrativa "mítica" e ficcional. Verbal e poético, musical e rítmico, esse eu poético adquire no desenvolvimento da composição poética uma notável densidade; ela traduz-se muitas vezes numa polifonia que se reflete na prática de sua performance. Esse é o caso em particular dos poemas corais pertencentes ao grande gênero do mélos, situados apressadamente sob a rubrica da lírica em razão da presença vultosa de um eu identificado de forma demasiado rápida e direta com o autor.

Tomando como exemplo único o poema mélico de Píndaro, pertencente ao gênero do epinício, convém ilustrar esse processo complexo de composição-performance musical que põe tanto a metáfora poética quanto a narrativa heróica a serviço de uma celebração ritual pelo prisma de um jogo enunciativo e pragmático de notável densidade.

\section{Imagens poéticas e eficácia do canto}

De Parmênides a Empédocles, passando por Simônides, Píndaro ou Baquílides, inúmeros são os poetas gregos da época pré-clássica que se convidam a subir na carruagem das Musas ou naquela de divindades aparentadas. $\mathrm{O}$ convite inscreve-se na poética helênica da inspiração musical. Funda-se em uma metáfora que encontramos, por exemplo, na poesia védica. Através do procedimento metafórico, a composição e a execução cantadas são assimiladas à participação numa corrida de carruagens. É assim que Parmênides, com a ajuda das filhas do Sol, alcança a porta da Noite e do Dia, onde o aguarda a Justiça divina; é assim que a Musa invocada por Empédocles conduz para o poeta a carruagem dócil que provém do reino da Piedade. ${ }^{8}$ Mas a metáfora fundada numa imagem verbal dinâmica como a da carruagem não é apanágio dos sábios pré-platônicos que recorrem à dicção épica; ela é também amplamente ativa em vários poetas mélicos, em particular nos cantos que celebram a vitória de um jovem atleta nos jogos pan-helênicos, em Delfos ou em Olímpia, mas também em Neméia ou no Istmo de Corinto.

8 Parmênides, fr. 28 B 1, 1-5 Diels-Kranz e Empédocles, fr. 31 B 3, 3-5 Diels-Kranz; quanto aos poetas mélicos, ver também Píndaro, Olímpica 9, 80-81, Ístmica 8, 61-62 etc.: demais exemplos, igualmente tomados de empréstimo à poesia védica, são mencionados por Nünlist (1998, p. 255-261); para a poesia grega, ver Auger (1987). 
Num canto de louvor destinado a um vencedor siciliano na corrida de carruagem dos jogos olímpicos de 472 ou 468 a.C., "Píndaro" compara a composição de seu poema à edificação de um palácio. Após fazer um primeiro elogio do vencedor ao estabelecer uma primeira relação entre Olímpia, local da prestação atlética, e Siracusa, cidade do vencedor, após tomar como testemunhas as Musas "com voz de mel" para seu louvor da bravura do nobre Hagêsias, o locutor não hesita em associar ao seu próprio poema a quadriga de mulas que obteve a vitória olímpica.

Ó Fíntis, vem, atrela agora

para mim as mulas vigorosas,

o mais rápido possível, para que guiemos nossa carruagem

por uma trilha livre e eu chegue à própria linhagem

da família de Hagêsias, porque essas mulas, mais que todas as outras,

sabem como tomar a frente

nesse caminho, elas que ganharam coroas

em Olímpia. Devemos portanto lhes abrir

de par em par os portões da canção,

pois hoje é preciso ir a Pitana

pelo curso do Eurotas em boa hora.

Assim, na segunda tríade da sexta Olímpica, aquele que diz eu, o locutor, dirige-se diretamente ao $t u$, ao cocheiro da quadriga; o cocheiro Fíntis é o representante em Olímpia de Hagêsias, o aristocrata de Siracusa que financiou o treinamento das parelhas do vencedor. O poeta pede ao jovem que atrele suas mulas e as conduza com sua carruagem "abrindo-lhes de par em par as portas do hino" (v. 27). Por metáfora interposta, o presente canto torna-se o meio de um deslocamento cuja expressão poética, note-se, lança mão da metáfora do caminho (kéleuthos, v. 23; hodós, v. 25). Mas longe de nos conduzir de Olímpia a Siracusa, onde o movimento enunciativo do poema nos situou de início, longe de nos transportar do local da vitória na corrida ao lugar provável de sua celebração e da execução do poema, o canto-parelha nos conduz ao Eurotas, na Lacônia, ao distrito de Pitana, que é um dos bairros de Esparta. Esse deslocamento geográfico imprevisto é acompanhado de um movimento temporal não menos surpreendente: de "hoje" (sámeron, v. 28), que corresponde ao tempo de enunciação do canto ("discurso") ao passado indeterminado, ao tempo narrativo e divino; é o tempo "mítico" no curso do qual o deus Posêidon uniu-se à jovem Pitana, ninfa epônima do distrito de Esparta. ${ }^{9} \mathrm{O}$

9 Píndaro, Olímpica 6, 22-42; a questão bastante controversa da data e das circunstâncias de enunciação desse poema complexo é retomada por Froidefond (1989, p. 29-48), que 
movimento de atrelagem transformado em poema duplica-se, portanto, num movimento enunciativo que, ao nos fazer passar do plano do "discurso" ao da "narrativa", nos arrasta ao mundo da ação heróica e, assim, do mito.

Dessa união divina e secreta - prossegue a narrativa poética - nasceu Evadne, que foi educada na Arcádia, perto do Alfeu, antes de ser por sua vez seduzida pelo jovem Apolo. Desse segundo amor de um deus com uma jovem mortal resultou Iamos. Nascido ele próprio junto ao Alfeu, no território da Arcádia, o herói está na origem de uma família de adivinhos, os iamidas; mas ele se revela igualmente o antepassado por parte de pai de Hagêsias de Siracusa, o patrocinador da parelha que obteve a vitória nos jogos olímpicos e que é cantado no epinício.

(Evadne), porém, depôs no chão seu cinto escarlate e sua urna de prata sob uma moita escarlate e deu à luz um menino de inspiração divina. Para ajudá-la, o deus de cabelos dourados enviou Elítia de conselhos gentis e as Parcas, e do seu útero, em meio

às bem-vindas dores de parto, Iamos veio imediatamente à luz.

Ficamos sabendo então que a criança, abandonada por sua mãe ninfa, foi alimentada, em meio às flores, pelo mel dispensado por duas serpentes. Associada pelo mel à doçura da sedução poética, a voz de Iamos será transformada, pela vontade de seu avô Posêidon e sobretudo pela intervenção de seu pai Apolo, senhor do oráculo de Delfos, numa voz de adivinho; o jovem herói é destinado então a transmitir a seus descendentes, os iamidas, essa dádiva de uma adivinhação inspirada, transmitida por uma voz de mel. Em seguida, é o próprio Apolo que instala Iamos em Olímpia; inspirado pelo deus de Delfos, o jovem herói funda às margens do Alfeu o oráculo que antecipa, junto ao altar de Zeus, a fundação por Héracles dos próprios jogos olímpicos.

se inclina para uma execução do poema não em Siracusa, mas em Estínfalo, na Arcádia, tal como Hutchinson (2001, p. 371-374); voltaremos ao assunto mais adiante. Sobre a seqüência de gestos de deixis que constitui a trama enunciativa desse poema, ver o belo estudo de Bonifazi (2001, p. 103-149). 
Assimilado à parelha do vencedor siracusano, o presente canto completa dessa maneira um percurso geográfico circular. Ao pôr entre parêntese um início siracusano, o itinerário desenhado pela metáfora da carruagem nos conduz, de fato, do local da prestação atlética junto ao Alfeu à Lacônia e à Esparta, para nos reconduzir, através de Pisatis e das fronteiras da Arcádia, à Olímpia. Esse itinerário geográfico duplica-se num percurso temporal que nos reconduz ao tempo da enunciação de que o poema era parte - e isso após uma longa incursão genealógica no passado divino e heróico da família dos iamidas, bem como no tempo original e "mítico" de um duplo ato fundador: o estabelecimento do oráculo em Olímpia, gerado pelos descendentes de Iamos, depois a fundação dos próprios jogos no tempo de Héracles. $\mathrm{O}$ desenho anular desse percurso narrativo e enunciativo contribui não somente para pôr em relação os atos fundadores do tempo mítico com o presente da performance do poema, mas também para traçar entre tempo e espaço do "mito" e o hic et nunc da enunciação cantada um laço de continuidade.

"Conduziremos a carruagem pelo caminho livre pelo qual pretendo juntarme à família de Hagêsias" (v. 23) - eu traduziria mais literalmente: no início desse percurso que se fecha sobre si mesmo, a alternância das formas auto-referenciais do singular e do plural (básomen, no plural, mas híkômai no singular, no mesmo verso 24) indica que esse deslocamento a uma vez espacial e temporal é assumido, pelo intermédio da imagem da parelha, por uma instância de enunciação que corresponde a uma situação de comunicação complexa; o eu/nós do locutor parece, de fato, incluir tanto o vencedor (o cocheiro da parelha vencedora em Olímpia, mantido por Hagêsias de Siracusa) quanto o poeta (Píndaro de Tebas, cocheiro do canto) e o provável grupo coral que executava a composição pindárica. Nesse trabalho de historiografia poética, de ordem geográfica e genealógica, assistimos portanto ao deslocamento do poeta com o cocheiro de Hagêsias, sobre a carruagem transformada em poema, rumo a Pitana, a Esparta, chegando até a Olímpia, passando pelas margens do Alfeu e pela Arcádia; esse percurso pode ser apenas metafórico. É da ordem da poesia, se não da ficção poética.

\section{Polifonia enunciativa e pragmática}

O itinerário metafórico, a uma vez narrativo e enunciativo, desenhado pela carruagem transformada em poema, diz respeito assim tanto ao poeta quanto a sua composição; tanto mais que, perto do final da ode, o locutor não se dirige mais ao jovem cocheiro do poderoso Hagêsias de Siracusa, mas, em eco, a um certo Enéas, cuja identidade está longe de assegurada, tanto o estilo desses versos é sintético. 
Minha avó por parte de mãe é de Estínfalo, Metope de belas flores, que deu à luz Tebe, domadora de cavalos, cuja água adorável eu beberei enquanto teço para lanceiros meu hino variado. Agora, Enéas, exorta teus companheiros a celebrarem primeiro

Hera, a Virgem, e depois a verem se por nossas palavras verdadeiras escapamos da velha pecha de "porco beócio", pois tu és um genuíno mensageiro, uma vareta de mensagem das Musas de bela cabeleira, uma cratera doce cheia de cantos sonoros.

"Genuíno mensageiro", "vareta de mensagem das Musas de bela cabeleira", "cratera doce cheia de cantos sonoros" (v. 90-91), o jovem não é outro senão o representante do poeta. A ele é conferida a tarefa de convidar "agora" (nûn, v. 87) seus companheiros (hetaîroi) a cantar a deusa, Hera Partênia, homenageada em Estínfalo, na Arcádia. Na tentativa de tradução em termos institucionais que propuseram os comentadores antigos dessa difícil passagem poética, isso significa que cabe a esse jovem mestre do coro treinar os coreutas para transmitirem, à maneira coral, a voz do poeta, agora, num momento que coincide com a execução do epinício, e num local que se quis identificar com a Estínfalo arcadiana. ${ }^{10}$

Ora, no verso que precede imediatamente esse apelo ao jovem mestre do grupo coral, o locutor e poeta expressa sua intenção de beber a água adorável da fonte Metope: "beberei" (píomai, v. 86), numa forma de futuro "performativo" que faz ainda coincidir globalmente o momento da inspiração poética com a performance do epinício. ${ }^{11}$ Mas essa evocação é a ocasião de uma segunda suspensão enunciativa e de uma segunda incursão no tempo da narrativa e do mito. Em novo percurso geográfico-genealógico, revela-se que Metope porta o nome de uma ninfa

10 Píndaro, Olímpica, 6, 82-99, com escólio ad v. 149a (I, p. 188 Drachmann). O papel desempenhado pelo jovem Enéas é bem definido por Bonifazi (2001, n. 13, 133-143); ver ainda as observações céticas formuladas por Heath (1988), bem como por Lefkowitz (1995). Sobre a sintaxe dessa passagem controversa, remetemo-nos ao útil comentário de Hutchinson (2001, n. 12, p. 413-415).

11 Sobre essa alusão à performance do poema num momento de inspiração e de composição que a forma intencional e "performativa" do futuro faz corresponder ao momento de sua execução, como ato de canto, ver em particular D’Alessio (2004, p. 289-290). 
de Estínfalo, na Arcádia, que outra não é senão a mãe de Tebe; e Tebe é ela mesma a ninfa epônima de Tebas, que, na Beócia, coincide com a pátria do poeta! Do local ainda vago da enunciação, passamos assim enunciativamente não mais ao local da prestação atlética e de seus fundadores, mas a uma região vizinha do local de origem da família dos iamidas e, portanto, da família de Hagêsias, numa provável alusão a sua ascendência maternal; a seguir, da Arcádia dos iamidas somos enviados de volta ao local não mais da execução, mas da composição do poema, por Píndaro de Tebas. De fato, é graças à inspiração encontrada junto à fonte Metope, "minha avó por parte de mãe" (v. 84), que o locutor-eu agora é capaz, numa outra metáfora freqüente na poesia mélica, de "tecer um canto variado" (plékôn, v. 86-87). ${ }^{12}$

Graças a esse segundo retorno (parcialmente implícito) aos locais e ao tempo do "discurso em ato" e da execução do poema, graças ao novo itinerário geográfico e genealógico (e portanto "mítico") proposto pelo locutor, assistimos a uma sutil explicitação figurada e poética de um jogo enunciativo freqüente na poesia mélica, em particular nos epinícios de Píndaro e de Baquílides, a saber: pela alternância de formas do eu e do nós, o jogo da "delegação coral" permite revezar a voz do poetacompositor com a voz do grupo coral das executantes ou dos executantes do poema. Não é por acaso, portanto, que os comentadores antigos atribuem ao jovem Enéas o título e a função de khorodidáskalos. ${ }^{13}$ Esse mestre do coro serve de intermediário entre a voz inspirada do locutor-eu e a voz coral dos jovens cantores que assume a execução do poema; no plano extra-discursivo, Enéas serve de intermediário entre o poeta compositor do poema (em Tebas) e o grupo coral dos executantes que o cantam numa dança ritual (provavelmente em Siracusa). Essa notável polifonia enunciativa torna ociosa, em muitos aspectos, a disputa acerca da natureza do "eu lírico" nos epinícios de Píndaro: nem unicamente "monódico", nem inteiramente coral, o eu/nós do locutor é essencialmente polifônico. ${ }^{14}$

12 A relação que o poeta estabelece entre Tebas, sua cidade e a genealogia dos iamidas é retraçada por Kurke (1991, p. 147-149) e por Hutchinson (2001, n. 12, p. 410-413). Para as diversas metáforas que associam a inspiração poética ao escoamento de um líquido, ver Nünlist (1998, n. 10, p. 195-199); para a arte da tecelagem, Nünlist (1998, p. 110-118), bem como Schieid e Svenbro (1994, p. 119-138).

13 Ver ainda os escólios ad v. 148a e 148c (I, p. 187 Drachmann); ver nesse sentido as considerações pertinentes de Vigneri (2000).

14 Além da sinopse de Lefkowitz (1995), acompanhada de abundante bibliografia, cf. por exemplo, a esse respeito, as observações pertinentes formuladas por D'Alessio (1994). 
Assim é que, de um lado, formula-se paradoxalmente na primeira pessoa do plural o desejo de evitar (pheúgomen) a censura endereçada ao "porco da Beócia", ${ }^{15}$ em referência não apenas à poética da verdade muitas vezes alegada pelo poeta dos Epinícios, mas também à sua origem tebana e portanto beócia. De outro lado, é ao mestre do coro Enéas que se transmite a incumbência de "dizer" (eîpon, v. 92), seja às Musas, seja a seus coreutas, que "se lembrem", e portanto que celebrem, Siracusa ao mesmo tempo que Ortígia. Enunciativamente, por diferentes movimentos de delegação, seja gramatical, seja explícita, as vozes do poeta, do khorodidáskalos e do grupo coral tendem a superpor-se.

Desde logo, do ponto de vista espacial e temporal, a passagem da metáfora à realidade da performance do poema de Píndaro é assegurada, ao termo do poema, pelo recurso à imagem não mais da parelha, mas do kômos (v. 98): imagem do cortejo processional, de uso freqüente em Píndaro. ${ }^{16}$ Nos últimos versos da sexta Olímpica, a ode em performance transforma-se em canto processional que celebra o vencedor siracusano Hagêsias. Os comentários antigos que chegaram até nós sob a forma de escólios revelam a menor reticência: glosam os numerosos exemplos pindáricos de kômos e kômázein pelos termos khorós e khoreúein; ${ }^{17}$ a seus olhos, a perfomance captada pela imagem da procissão só pode ser coral. Assim, o tirano de Siracusa, Hierão, é convidado a receber o jovem aristocrata que chega do local onde o poema o havia deixado: em Estínfalo. Recepção ritual provavelmente por ocasião de uma festa cultual (heortán, v. 95) organizada em homenagem a Deméter e a sua filha Perséfone que Enéas é instado a celebrar, com a ajuda provável das Musas; há de se lembrar que mãe e filha são duas das divindades tutelares da cidade, e que a família de Hierão lá exercia provavelmente o sacerdócio. Pelo e no canto processional, o kômos nos reconduz assim da Arcádia e mais especificamente de Estínfalo, próximo da pátria dos iamidas, assim como de Tebas, a pátria do poeta, rumo ao local e ao tempo de execução do poema, que não pode ser outro senão Siracusa. De fato, tanto a evocação final de hospitalidade poética demandada ao tirano de Siracusa quanto uma primeira alusão desde o início do poema ao "mestre siracusano do kômos" (v. 18) confirmam, pelo prisma de uma estrutura em

15 Sobre o sentido pejorativo dessa expressão proverbial, em referência à poética da censura, ver o comentário de Hutchinson (2001, n. 12, p. 416-417).

16 Cf., nesse sentido, as diversas referências que forneço em Calame (2005').

17 Ver as passagens enumeradas e comentadas por Vigneri (2000, n. 13). Cf. Carey (1991); sobre o sentido processional de kômos, consulte-se em particular Morgan (1993). 
anel, que a performance do epinício composto por Píndaro é recebido por essa brilhante cidade da Sicília. ${ }^{18}$

Oíkothen oíkade (v. 99), "da casa rumo a essa casa": gesto de dêixis correspondente a uma demonstratio ad oculos, esse movimento espacial final de uma pátria rumo a outra pátria parece confirmar a dupla ascendência dos membros da família de Hagêsias - descendentes dos iamidas originários da Arcádia (mais tarde estabelecidos em Olímpia), mas também cidadãos de Siracusa. Seja como for, esse movimento de retorno rumo a Siracusa é consagrado pela invocação dirigida ao deus Posêidon no final do epinício. Em complemento à metáfora dinâmica da parelha, a imagem do navio e de suas duas âncoras intervém aqui, como em outros epinícios, tanto para indicar o movimento do poema rumo a Siracusa quanto sua fixação sobre o local da execução: "Favoráveis são as duas âncoras que imobilizam, na tempestade noturna, o navio ligeiro". Invocado ao fim, o deus do mar torna-se então garante tanto da dupla origem de Hagêsias, arcadiano e siracusano, quanto do percurso do poema em performance: de Tebas e de Estínfalo rumo a Siracusa. Não é de modo algum por acaso, portanto, que o poema conclui com o pedido dirigido ao marido de Anfitrite para que faça florescer "meus hinos" (v. 105): retorno final à instância de enunciação, agora solidamente ancorada em Siracusa!

Senhor dos mares, garante uma travessia direta, livra de contratempos, marido de Anfitrite da roca dourada, faze crescer a flor agradável dos meus hinos.

\section{O aparato poético da enunciação e a narrativa mítica}

Apresentado como uma carruagem puramente metafórica quando se trata de retraçar, com o concurso figurado do cocheiro e de sua própria parelha, a ascendência geográfica e genealógica (Arcádia e Olímpia) da família do vencedor, o canto se realiza ao seu término em sua identidade coral e processional pela imagem do kômos, e depois por aquela do navio; executado em Siracusa, esse poema coral remonta genealogicamente a Tebas, a pátria de Píndaro. Assim, a imagem dupla da parelha e da procissão focaliza a composição de Píndaro, o tebano, no hic

18 A tripla estrutura em anel que finda nesse retorno final a Siracusa é descrita por Froidefond (1989, n. 13, p. 45-48). Sobre esse trajeto poético, ver a excelente leitura proposta por Goldhill (1991, p. 154-166). 
et nunc de sua performance: não mais em Olímpia, local da vitória atlética e da prática oracular dos iamidas, não mais em Estínfalo, local dos ascendentes maternos de Hagêsias (e quem sabe o local de origem de Enéas?), não mais em Tebas, local de residência de Píndaro e da composição do poema, mas em Siracusa, por ocasião de uma celebração cultual. Se o percurso geográfico e genealógico traçado pela parelha verbal até o tempo dos fundamentos míticos mantém-se poético e metafórico, aquele descrito na procissão ritual torna-se realidade, após o desvio genealógico por Tebe e Tebas na Beócia, na correspondência do tempo e do lugar de sua realização narrativa e discursiva com o "aqui" e o "agora" da execução do poema, um hic et nunc orientado pela instância de enunciação.

É portanto no eu poético que, ao termo da composição cantada, acabam por convergir a voz enunciativa do poeta inspirado, a voz coral dos atores do kômos, a voz do seu khorodidáskalos. A notável densidade semântica desse eu poético é essencialmente polifônica. Mas graças às balizas temporais e sobretudo espaciais que apontamos (Siracusa, Esparta, Olímpia, Arcádia, Entínfalo, Tebas), graças ainda (e de maneira paradoxal) aos trajetos geográfico-genealógicos no tempo e no espaço ficcionais dos "mitos" fundadores, essa instância enunciativa polifônica recebe uma referência extra-discursiva precisa.

Do lado do eu/nós:

- Píndaro de Tebas, na condição de poeta inspirado e mestre da verdade,

- Enéas (de Estínfalo), como khorodidáskalos,

- os jovens coreutas de Siracusa,

- finalmente o próprio poema (objetivado em ele pela assimilação com a parelha de corrida);

do lado do tu:

- Hagêsias, arcadiano de Siracusa,

- Fíntis, o cocheiro siracusano,

- Hierão, o tirano de Siracusa

- Posêidon, o deus do mar que circunda Siracusa.

À complexidade polifônica da instância de enunciação, à sua densidade semântica e discursiva corresponde uma "função-autor" singularmente desenvolvida; pela metáfora da carruagem e pela imagem do kômos como canto processional e ritual, ela remete-se à performance do poema. 
Estamos, portanto, bem longe da noção romântica do "eu lírico", a quem caberia assumir diretamente a expressão verbal dos sentimentos pessoais do poetaescritor, do poeta biográfico; estamos bem longe da intencionalidade de um indivíduo-poeta, sujeito criador autônomo que romperia com a tradição poética na qual se inscreve. ${ }^{19}$ Sem dúvida inegável, a vontade da criação poética é filtrada por uma dicção poética tradicional, pelas regras do gênero, pelas exigências da ocasião ritual, pelo desdobramento na performance poética da "função-autor", pelas estratégias enunciativas de ordem poética.

Em particular no exemplo poético escolhido, o jogo da metáfora poética apóia-se no objeto que se desloca (símbolo da prestação no concurso atlético) para conferir movimento ao canto, à prestação poética e musical representada no poema por um jogo enunciativo complexo; com esse efeito pragmático enunciativo e espácio-temporal, transfere-se a imagem apropriada à vitória nos jogos ao hic et nunc da performance ritual do canto, assumido por um eu polifônico de extraordinária densidade. $O$ fato de o canto ser posto em movimento pela imagem é fundamental em poemas que, pelas numerosas intervenções auto-referenciais, se apresentam como atos de canto: speech-acts que, pela referência enunciativa à atividade musical que é aquela dos executantes do poema, se transformam em song-acts. Na medida em que sua execução insere-se em geral numa celebração ritual para um dos deuses tutelares da cidade, esses atos de canto são também cult-acts, atos de culto. No que respeita ao epinício, eles têm por efeito religioso e político enriquecer e preservar não apenas a memória da família aristocrática daquele que se tornou ilustre nos jogos pan-helênicos, mas também a memória coletiva da comunidade cívica à qual ele pertence; isso através de poderosas imagens verbais, desdobradas e tornadas eficazes pelo aparato poético da enunciação do canto ritual; isso pelo prisma desses trajetos ascendentes no tempo heróico e divino dos atos fundadores e civilizadores.

Não há, portanto, uma mitografia, mas uma mito-logia cuja lógica não é unicamente narrativa, mas também enunciativa, em relação com uma forma poética cantada que insere a narrativa mítica numa espácio-temporalidade em relação com o presente e que, na performance, como ato de canto, faz da narração mítica um ato ritual, assumido coletivamente. Nessa ritualidade da enunciação do canto, a polifonia autoral do poema inscreve a referência mítica numa memória cultural prática, coletivamente partilhada.

19 Digo isso para contradizer abertamente o princípio antiquado que norteia a hermenêutica filológica "crítica" enaltecida à exaustão por Bollack, por exemplo em seu último ensaio, Parménide, de l'étant au monde (Bollack, 2006). 


\section{REFERÊNCIAS Bibliográficas}

Auger, D. "De l'artisan à l'athlète: les métaphores de la création poétique dans l'épinicie et chez Pindare". In: Costantini, M.; Lallot, J. et al. (ed.). Le texte et ses représentations, Paris: ENS, 1987. p. 39-56.

Benveniste, E. Problèmes de linguistique générale. Paris: Gallimard, 1966, 1974.

BIERL, A. Der Chor in der alten Komödie. Ritual und Performativität. München / Leipzig:

K. G. Saur, 2001.

Bollack, J. Parménide, de l'étant au monde. Lagrasse: Verdier, 2006.

Bonifazi, A. Mescolare un cratere di canti. Alessandria: Edizioni dell'Orso, 2001.

BüHLER, K. Sprachtheorie. Die Darstellungsfunktion der Sprache. Jena: G. Fischer, 1934.

(trad. ingl.: Theory of Language. The Representational Function of Language. Philadelphia: J. Benjamins, 1990.)

CAlame, C. "Identifications génériques entre marques discursives et pratiques énonciatives: pragmatique des genres 'lyriques”. In: BARONI, R.; MACÉ, M. (ed.). Le savoir des genres. Rennes: La Licorne, 2006. p. 35-55.

. Masques d'autorité. Fiction et pragmatique dans la poétique grecque antique. Paris: Les Belles Lettres, 2005.

. "Pragmatique de la fiction: quelques procédures de deixis narrative et énonciative en comparaison (poétique grecque)". In: ADAM, J.-M.; HeIDMANN, U. (ed.). Sciences du texte et analyse de discours. Enjeux d'une interdisciplinarité. Lausanne / Genève: Études de Lettres / Slatkine, 2005'. p. 119-143.

. Le récit en Grèce ancienne. Énonciations et représentations de poètes. 2 ed. Paris: Belin, 2002.

. Poétique des mythes dans la Grèce antique. Paris: Hachette, 2000.

. "La poésie lyrique grecque, un genre inexistant? ". Littérature. v. 111, p. 87 110, 1998.

. (ed.) Métamorphoses du mythe en Grèce antique. Genebra: Labor \& Fides, 1988.

Calame, C.; Chartier, R. (ed.). Identités d'auteur dans l'Antiquité et la tradition européenne. Grenoble: Jérôme Millon, 2004.

Carey, C. "The Victory ode in Performance: The Case for the Chorus". Classical Philology. v. 86, p. 192-200, 1991.

D'Alessio, G. B. "Past Future and Present Past: Temporal Deixis in Greek Archaic Lyric”. Arethusa. v. 37, p. 267-294, 2004. 
. "First-person problems in Pindar". Bulletin of the Institute of Classical Studies. v. 39, p. 117-139, 1994.

Delattre, C. Manuel de mythologie grecque. Paris: Bréal, 2005. . (ed.). Mythe, imaginaire, fiction. Paris: no prelo.

Froidefond, C. Lire Pindare. Namur: Société des Études Classiques, 1989.

Goldhill, S. The Poet's Voice. Essays on Poetics and Greek Literature. Cambridge: Cambridge University Press, 1991.

Heath, M. "Receiving the kômos: The Context and Performance of Epinician". American Journal of Philology. v. 109, p. 180-195, 1988.

Hutchinson, G. O. Greek Lyric Poetry. A Commentary on Selected Larger Pieces. Oxford: Oxford University Press, 2001.

Kunke, L. The Traffic in Praise. Pindar and the Poetics of Social Economy. Ithaca / London: Cornell University Press, 1991.

Lefkowitz, M. "The First Person in Pindar Reconsidered - Again". Bulletin of the Institute of Classical Studies. v. 40, p. 139-150, 1995.

Morgan, K. A. "Pindar the Professional and the Rhetoric of the kômos". Classical Philology. v. 88, p. 1-15, 1993.

NüNLIST, R. Poetologische Bildersprache in der frühgriechischen Dichtung. Stuttgart / Leipzig: Teubner, 1998.

Scheid, J.; Svenbro, J. Le métier de Zeus. Mythes du tissage et du tissu dans le monde gréco-romain. Paris: La Découverte, 1994.

VIGNERI, V. "Il coro dell'epinicio pindarico negli scholia vetera". Quaderni Urbinati di Cultura Classica. v. 95, p. 87-103, 2000.

CALAME, C. Entre récit historique et poésie rituelle: le sujet poétique qui chante le mythe.

RÉSUMÉ: Le croisement de la perspective ouverte par les recherches de Benveniste sur l'énonciation entre récit (/énoncé) et discours (énoncé de l'énonciation) et celles de Bühler sur les procédures de la deixis à partir $d u$ point focal que constitue le je discursif ont un impact non seulement sur la conception de l'auteur et de son autorité poétique, mais aussi sur celle de la fiction en général et du mythe en particulier dans leur dimension discursive. Pour la poésie de la Grèce classique que nous avons constituée en "littérature" en dépit de son caractère fortement pragmatique qui en 
destine les formes à des performances musicales ritualisées, c'est donc non seulement la question du je poétique (et "lyrique") qui doit être envisagée sous un jour nouveau, mais également celle de ces récits que nous dénommons "mythiques" parce que nous doutons de leur référence empirique et que nous les assimilons à des fictions. À l'exemple unique d'un poème mélique de Pindare appartenant au genre de l'épinicie, il convient d'illustrer ce processus complexe de composition-performance musicale qui met aussi bien la métaphore poétique que le récit héroïque au service d'une célébration rituelle par le biais d'une jeu énonciatif et pragmatique d'une remarquable densité.

MOTS-CLEFS: mélos; poésie rituelle; récit et discours; "je lyrique".

Tradução de

JOSÉ MARCOS MARIANI DE MACEDO

PPG Letras Clássicas

FFLCH/USP 